\title{
The $\sigma$-Receptor Antagonist BD-1063 Decreases Ethanol Intake and Reinforcement in Animal Models of Excessive Drinking
}

\author{
Valentina Sabino*, 1,2,7, Pietro Cottone ${ }^{1,2,7}$, Yu Zhao', Malliga R lyer $^{3}$, Luca Steardo Jr ${ }^{4}$, Luca Steardo ${ }^{5}$, \\ Kenner C Rice ${ }^{3}$, Bruno Conti ${ }^{2,6}$, George F Koob' and Eric P Zorrilla ${ }^{\text {*, }, 2}$ \\ 'Committee on the Neurobiology of Addictive Disorders, The Scripps Research Institute, La Jolla, CA, USA; ${ }^{2}$ Harold L. Dorris Neurological \\ Research Institute, The Scripps Research Institute, La Jolla, CA, USA; ${ }^{3}$ Chemical Biology Research Branch, National Institute on Drug Abuse and \\ the National Institute on Alcohol Abuse and Alcoholism, Rockville, MD, USA; ${ }^{4}$ Department of Psychiatry, University of Naples SUN, Naples, Italy; \\ ${ }^{5}$ Department of Human Physiology and Pharmacology, University of Rome La Sapienza, Rome, Italy; ${ }^{6}$ Molecular and Integrative Neurosciences \\ Department, The Scripps Research Institute, La Jolla, CA, USA
}

$\sigma$-Receptors (SigRs) have been implicated in behavioral and appetitive effects of psychostimulants and may also modulate the motivating properties of ethanol. This study tested the hypothesis that SigRs modulate ethanol reinforcement and contribute to excessive ethanol intake. The effects of subcutaneous treatment with the potent, selective Sig-IR antagonist BD-I063 on operant ethanol selfadministration were studied in two models of excessive drinking - Sardinian alcohol-preferring (sP) rats and acutely withdrawn ethanoldependent Wistar rats - and compared to ethanol self-administration in nondependent Wistar controls. To assess the specificity of action, the effects of BD- 1063 on self-administration of an equally reinforcing saccharin solution were determined in Wistar and sP rats. Gene expression of Sig- IR in reward-related brain areas implicated in ethanol reinforcement was compared between ethanol-naive sP and Wistar rats and withdrawn ethanol-dependent Wistar rats. BD- 1063 dose dependently reduced ethanol self-administration in sP rats $(3.3-11 \mathrm{mg} / \mathrm{kg})$ and withdrawn, dependent Wistar rats $(4-11 \mathrm{mg} / \mathrm{kg})$ at doses that did not modify mean ethanol self-administration in nondependent Wistar controls. BD-1063 did not reduce concurrent water self-administration and did not comparably suppress saccharin self-administration, suggesting selectivity of action. BD- 1063 also reduced the breakpoints of sP rats to work for ethanol under a progressive-ratio reinforcement schedule. Ethanol-naive SP rats and 24-h withdrawn, dependent Wistar rats showed reduced Sig-IR mRNA expression in the nucleus accumbens. The results suggest that SigR systems may contribute to innate or ethanol-induced increases in susceptibility to self-administer high ethanol levels, identifying a potential neuroadaptive mechanism contributing to excessive drinking and a therapeutic target for alcohol abuse and dependence.

Neuropsychopharmacology (2009) 34, |482- |493; doi:10.1038/npp.2008.192; published online 22 October 2008

Keywords: sigma receptor antagonist; alcohol or ethanol; abstinence or withdrawal; dependence or addiction or alcoholism; self-administration; Sardinian alcohol-preferring rats

\section{INTRODUCTION}

Alcoholism is a multifactorial, chronic disorder of compulsive alcohol use (McLellan et al, 2000). Animal models that mimic alcoholism are unattainable, but syndrome components can be modeled (Koob et al, 1998). Excessive ethanol self-administration has been observed in rodents selectively bred for ethanol intake and in outbred rats withdrawn from

*Correspondence: Dr V Sabino or Dr EP Zorrilla, Committee on the Neurobiology of Addictive Disorders, SP30-2400, The Scripps Research Institute, 10550 N. Torrey Pines Road, La Jolla, CA 92037, USA, Tel: + 8587847470 or 858784 7416, Fax: 8587847405 ,

E-mails: vsabino@scripps.edu or ezorrilla@scripps.edu

${ }^{7}$ These authors contributed equally to this work.

Received 25 August 2008; revised 18 September 2008; accepted 20 September 2008 ethanol following induction of ethanol dependence (McBride and Li, 1998; Rimondini et al, 2002; Roberts et al, 2000; Rogers et al, 1979). Use of such animal models has identified a role for opioid peptide systems in the acute reinforcing effects of ethanol and excessive drinking (Lovinger and Crabbe, 2005). Although much work has explored the role of opioid peptide systems and related peptides (eg nociceptin) on the reinforcing effects of ethanol, little work has examined the role of $\sigma$-receptors (SigRs).

SigRs were originally categorized as members of the opioid receptor family (Martin et al, 1976) and a highaffinity phencyclidine-binding site (Quirion et al, 1981). However, it is now known that SigRs are unique binding sites that differ from other known mammalian proteins (Gundlach et al, 1985; Walker et al, 1990). Two different SigR subtypes are known, Sig-1R and Sig-2R, differing in 
their binding profile and molecular weight (Hanner et al, 1996; Hellewell and Bowen, 1990; Moebius et al, 1993). The Sig-1R gene (Mei and Pasternak, 2001; Pan et al, 1998; Seth et al, 1998) encodes a $29 \mathrm{kDa}$ polypeptide containing one or two putative transmembrane domains. Sig-1Rs are synthesized and expressed widely in rat brain, especially throughout limbic areas and brainstem motor structures. The highest levels of immunoreactivity are observed in the olfactory bulb, hypothalamus, and hippocampus, but the caudate putamen, septum, nucleus accumbens, and amygdala show moderately concentrated, intense labeling (Alonso et al, 2000; Bouchard and Quirion, 1997; Phan et al, 2003). The anatomical distribution of SigRs, which immunostain at synaptic contacts (Maurice et al, 2002; Alonso et al, 2000), suggests that SigRs may modulate motivationally relevant synaptic transmission, including that of drugs of abuse.

Accordingly, SigRs are implicated in actions of psychostimulants. SigR antagonists block cocaine-induced c-fos expression, locomotion, place preference conditioning, seizures, and lethality in rodents (Maurice and Romieu, 2004; McCracken et al, 1999; Menkel et al, 1991; Witkin et al, 1993). Likewise, the SigR antagonists BD-1063 and/or BD-1047 attenuated the locomotor stimulatory effects of methamphetamine and 3,4-methylenedioxymethamphetamine in mice (Brammer et al, 2006; Romieu et al, 2002), and MS-377 attenuated the development of behavioral sensitization to methamphetamine (Takahashi et al, 2000). A SigR antagonist also attenuated contextual reinstatement of cocaine-directed responding (Martin-Fardon et al, 2007). Many actions of SigR antagonists are shared by Sig-1R receptor antisense oligodeoxynucleotides (Brammer et al, 2006; Romieu et al, 2002). Furthermore, repeated passive cocaine (Romieu et al, 2002) and methamphetamine exposure (Itzhak, 1993) increased Sig-1R mRNA expression in several discrete brain regions, as did daily methamphetamine self-administration (Stefanski et al, 2004). Accordingly, activation and overexpression of Sig-1Rs are putative primary cellular responses to psychostimulants proposed to underlie addiction-associated neuroadaptations (Maurice and Romieu, 2004; Su and Hayashi, 2003; Takebayashi et al, 2002).

Few studies have examined SigR involvement in ethanol's actions. Although it often has been assumed that SigR antagonist-sensitive actions of cocaine and methamphetamine reflect direct molecular interactions, the psychostimulants in fact bind with only micromolar affinity to SigRs (Brammer et al, 2006; Nguyen et al, 2005; Sharkey et al, 1988). Thus, indirect SigR-mediated effects may exist for all substances of abuse, including ethanol. Indeed, the SigR antagonist BD-1047 dose dependently attenuated ethanolinduced locomotion and blocked ethanol-induced place and taste conditioning. Moreover, Sig-1R gene functional polymorphisms that correlate with alterations in receptor transcription were overrepresented in a Japanese population of alcoholic subjects (Miyatake et al, 2004). The purpose of this study was therefore to test the hypothesis that SigRs modulate reinforcing effects of ethanol. For this, we examined the effects of systemic administration of the SigR antagonist BD-1063 on operant oral ethanol self-administration in dependent Wistar rats withdrawn from repeated, intermittent ethanol vapor exposure and in genetically selected Sardinian alcohol-preferring $(\mathrm{sP})$ rats (Colombo,
1997; Colombo et al, 1995). To assess the selectivity of action against high ('excessive') ethanol drinking, results were compared to those seen in nondependent, outbred Wistar rats and against similar rates of saccharin selfadministration. Finally, gene expression of Sig-1R in several reward-related brain areas putatively implicated in ethanol reinforcement (eg nucleus accumbens, ventral tegmental area, central nucleus of the amygdala, basolateral amygdala; Vengeliene et al, 2008) were compared between ethanolnaive $\mathrm{sP}$ and Wistar rats and acutely withdrawn, dependent Wistar rats.

\section{MATERIALS AND METHODS}

\section{Animals}

Male Wistar rats ( $n=61$; Charles River, Raleigh, NC) and genetically selected TSRI sP rats $(n=34)$ were subjects. TSRI sP rats were generated from the 22nd to 24th generations of intraline breeding at The Scripps Research Institute from $\mathrm{sP}$ rats obtained after 32 generations of selection from Professor GL Gessa (University of Cagliari). Rats, $300 \mathrm{~g}$ at study onset, were group-housed (2-3 per cage) in a humidity- and temperature $\left(22^{\circ} \mathrm{C}\right)$-controlled vivarium on a 12-h light-dark cycle (lights off, 0800 hours) with water and chow (Harlan Teklad 7012) available ad libitum. Procedures adhered to the National Institutes of Health Guide for the Care and Use of Laboratory Animals and were approved by the Institutional Animal Care and Use Committee of The Scripps Research Institute.

\section{Drugs}

Ethanol $(10 \% \mathrm{v} / \mathrm{v})$ and saccharin solutions were prepared in tap water using $95 \%$ ethyl alcohol and saccharin sodium salt hydrate (Sigma-Aldrich, catalog number S1002), respectively. BD-1063 $2 \times \mathrm{HBr}$ salt (1-(2-(3,4-dichlorophenyl)ethyl)-4-methylpiperazine dihydrobromide) was synthesized according to the previously reported procedure (de Costa et al, 1993). BD-1063 was solubilized in isotonic saline and injected subcutaneously (s.c. $1 \mathrm{ml} / \mathrm{kg}$ ), $15 \mathrm{~min}$ before testing.

\section{Oral Self-Administration Apparatus}

The self-administration test chambers (Coulbourn Instruments, Allentown, PA) were located in sound-attenuating, ventilated environmental cubicles. Syringe pumps (Razel Scientific Instruments, Stamford, CT) dispensed ethanol or water into two stainless steel drinking cups mounted $4 \mathrm{~cm}$ above the grid floor in the middle of one side panel. Two retractable levers were located $4.5 \mathrm{~cm}$ to either side of the drinking cups. Fluid delivery and recording of operant responses were controlled by microcomputers.

\section{Ethanol Self-Administration Procedure}

Outbred Wistar rats. Wistar rats were allowed to press a lever for ethanol on a fixed ratio-1 (FR1) schedule of reinforcement via a modified Samson fading procedure (Funk et al, 2006). Briefly, rats first responded for $0.1 \mathrm{ml}$ of a glucose $(3 \% \mathrm{w} / \mathrm{v}) /$ saccharin $(0.125 \% \mathrm{w} / \mathrm{v})$ solution for 5 sessions. 
Then, ethanol self-administration was initiated by adding ethanol $(10 \% \mathrm{v} / \mathrm{v})$ to the sweet solution for 4-5 sessions, followed by $4-5$ sessions of $10 \%$ ethanol $+0.125 \%$ saccharin only. Finally, rats received operant access to the $10 \%$ ethanol solution alone. During training, subjects received a 30-min self-administration session 5 days per week.

$s P$ rats. Sardinian alcohol-preferring rats were allowed to self-administer $10 \% \mathrm{v} / \mathrm{v}$ ethanol without a fading procedure under an FR1 reinforcement schedule, as previously described (Sabino et al, 2006). Lever presses had no scheduled consequences for $2.01 \mathrm{~s}$ after the activation of the pumps to avoid double responses (Sabino et al, 2006). For training, rats received a daily 60 -min self-administration session 5 days per week until performance stabilized ( $<15 \%$ variation across three consecutive sessions). For both Wistar and $\mathrm{s}$ rats, responses at the opposite lever produced water, with the lever that produced water or ethanol alternated daily during training.

Separate animals were allowed to self-administer $10 \% \mathrm{v} / \mathrm{v}$ ethanol under a progressive ratio (PR) schedule of reinforcement in which the number of responses required to produce successive ethanol deliveries increased per the exponential progression: response ratio $=4 \times$ $\left(e^{\text {no. }}\right.$ of reinforcer $\left.\times 0.1\right)-3.8$, rounded to the nearest integer. The session began upon completion of the first ratio with a maximum duration of $2 \mathrm{~h}$. To avoid unintended session starts, the first reinforcement required three responses. Sessions ended when subjects did not complete a ratio for $15 \mathrm{~min}$. The dependent measures were the following: (a) breakpoint, last ratio completed by a subject before the end of the session; (b) total responses, total number of reinforced and nonreinforced responses; (c) reinforcers, total number of reinforced responses. Testing, performed between 1500 hours and 1800 hours twice per week, began when stable responding was achieved $(<15 \%$ variation across three consecutive sessions).

\section{Saccharin Self-Administration Procedure}

Rats were allowed 1-2 overnight (16-h) operant, 2-choice access sessions during which lever responses led to delivery of $0.1 \mathrm{ml}$ saccharin $(0.1 \% \mathrm{w} / \mathrm{v})$ or water solutions under an FR1 schedule. Food was available ad libitum. All subsequent FR1 sessions were $60 \mathrm{~min}$ in duration, without food present, with saccharin concentrations reduced progressively from $0.1 \% \mathrm{w} / \mathrm{v}$ to $0.0035 \% \mathrm{w} / \mathrm{v}$ for Wistar rats and to $0.045 \% \mathrm{w} / \mathrm{v}$ for sP rats. These concentrations maintained response rates similar to those elicited by ethanol in dependent Wistar rats and $\mathrm{sP}$ rats, respectively.

\section{Ethanol Vapor Exposure Procedure}

To induce dependence, Wistar rats were housed within sealed, clear plastic chambers into which ethanol vapor was intermittently introduced, as described previously (Sabino et al, 2006). The chambers were connected to a timer that turned the ethanol vapor on (2000 hours) and off (1000 hours), for $14 \mathrm{~h}$ of daily ethanol exposure. Tail blood $(0.05 \mathrm{ml})$ was sampled at vapor offset for blood alcohol level (BAL) determination twice during the first week and weekly thereafter. The plasma was extracted with trichloroacetic acid and assayed for ethanol content using the nicotinamide adenine dinucleotide-alcohol dehydrogenase enzyme spectrophotometric method (Sigma). Target BALs were 150$200 \mathrm{mg} \%$ across a 6 -week exposure period. This paradigm induces physical dependence and increases operant ethanol self-administration during withdrawal (Funk et al, 2006; O'Dell et al, 2004; Sabino et al, 2006); control rats were kept under similar conditions without ethanol vapor exposure.

After 6 weeks of exposure, rats in the self-administration experiment were tested for operant ethanol self-administration twice weekly, beginning $6 \mathrm{~h}$ after vapor offset. The first four of these 30 -min sessions allowed subjects to experience the potential negative reinforcing effects of ethanol during acute withdrawal, after which experimental testing was initiated. Rats in the qPCR experiment were instead anesthetized by isoflurane inhalation (6 or $24 \mathrm{~h}$ after vapor offset) and decapitated. Brains were sectioned coronally ( $2 \mathrm{~mm}$ slices) in a rat brain matrix. Brain regions of interest (nucleus accumbens, ventral tegmental area, central nucleus of the amygdala basolateral amygdala), chosen for their role in reward and reinforcement and moderate-to-high SigR expression (Alonso et al, 2000; Bouchard and Quirion, 1997), were punched using a 14gauge needle, guided by atlas (Palkovits, 1988), and stored at $-80^{\circ} \mathrm{C}$ until processing. Naive $\mathrm{sP}$ rats were sacrificed together with the $6 \mathrm{~h}$ withdrawal Wistar rat group.

\section{Effects of BD-1063 on Ethanol Self-Administration}

Outbred Wistar rats. Rats (controls, $N=11$; dependents, $N=9)$ were pretreated with BD-1063 $(0,4.4,7$, and $11 \mathrm{mg} / \mathrm{kg}$ of body weight, free base basis, s.c.) using a within-subject Latin square design.

$s P$ rats. Rats $(N=9)$ were pretreated with $\mathrm{BD}-1063(0,3,4.4$, 7 , and $11 \mathrm{mg} / \mathrm{kg}$ of body weight, free base basis, s.c.) using a within-subject Latin square design.

\section{Effects of BD-1063 on Progressive-Ratio Ethanol Self- Administration}

Sardinian alcohol-preferring rats $(N=11)$ were pretreated with $\mathrm{BD}-1063(0,3,4.4,7$, and $11 \mathrm{mg} / \mathrm{kg}$, s.c.) using a withinsubject Latin square design.

\section{Effects of BD-1063 on Saccharin Self-Administration}

Rats were pretreated with BD-1063 (Wistar: 0, 4.4, 7, $11 \mathrm{mg}$ / $\mathrm{kg}, N=8$; sP: $0,3,4.4,7,11 \mathrm{mg} / \mathrm{kg}, N=7)$ using a withinsubject Latin square design.

\section{Sig-1R Gene Expression}

Total RNA was prepared from each punch using the RNeasy mini kit (Qiagen, Valencia, CA) as recommended for animal tissue. Total RNA $(1 \mu \mathrm{g})$, quantified by Ribogreen reagent (Molecular Probes, Invitrogen, Carlsbad, CA), was reverse transcribed with SuperScript First-Strand Synthesis System for RT-PCR (Invitrogen) in the presence of Oligo (dT) ${ }_{12-18}$ per the manufacturer's instructions. For quantitative realtime PCR, Roche Light Cycler 480 Master-plus SYBR Green mix (Roche Applied Science, Indianapolis, IN) was used. 
Reactions $(20 \mu \mathrm{l})$ were carried out in a 96-well plate Realplex ${ }^{4}$ machine (Eppendorf). The primers $(0.5 \mu \mathrm{M}$ final concentration; Valuegene, San Diego, CA), synthesized with a standard desalting purification, were for Cyclophilin A (Cyp), 5'-TATCTGCACTGCCAAGACTGAGTG-3' and $5^{\prime}$-CT TCTTGCTGGTCTTGCCATTCC- $3^{\prime}$, and for Sig-1R, $5^{\prime}$-GCTG CAGTGGGTGTTTGTGAACG- $3^{\prime}$ and $5^{\prime}$-GGTGGAAAGTGCC AGAGATGATGGTA-3'. The Cyp sequence was amplified using a three-temperature protocol, which included an initial $5 \mathrm{~min}$ at $94^{\circ} \mathrm{C}$ to activate Taq polymerase, followed by 40 denaturation cycles at $95^{\circ} \mathrm{C}$ for $20 \mathrm{~s}$, annealing at $58^{\circ} \mathrm{C}$ for $15 \mathrm{~s}$, and extension at $72^{\circ} \mathrm{C}$ for $10 \mathrm{~s}$. The Sig-1R sequence was amplified per a two-temperature protocol after an initial $5 \mathrm{~min}$ at $94^{\circ} \mathrm{C}$ : 40 cycles at $94^{\circ} \mathrm{C}$ for $15 \mathrm{~s}$ and at $68^{\circ} \mathrm{C}$ for $8 \mathrm{~s}$. The primers for Sig-1R hybridize to sequences within exons 3 and 4 of the Oprs- 1 transcript and therefore amplify the 'long' isoform of the protein, corresponding to the characterized receptor (Ganapathy et al, 1999). Standard curves were constructed using sequenced PCR products. Results were analyzed by second derivative methods and expressed in arbitrary units, normalized to Cyp expression levels. Standards and samples were run in duplicate, and all reactions for a given brain region were performed concurrently. Gene-specific amplification was determined by melting curve analysis as one peak at the expected melting temperature and by agarose gel electrophoresis.

\section{Statistical Analysis}

Ethanol responding data were analyzed by analyses of variance (ANOVAs) and expressed as mean \pm SEM, normalized for body weight (ie ethanol, $\mathrm{g} / \mathrm{kg}$; water and saccharin, $\mathrm{ml} / \mathrm{kg}$ ). The effects of BD-1063 on ethanol and saccharin responding in $\mathrm{sP}$ rats were analyzed by separate one-way ANOVAs with dose of BD-1063 as a within-subject factor. The effects of BD-1063 on ethanol responding in Wistar rats were analyzed by a two-way ANOVA with ethanol history (dependent $v s$ nondependent) as a between-subjects factor and dose of BD-1063 as a within-subject factor. Unless otherwise specified, Dunnett's test was used for pairwise comparisons after significant omnibus tests. Quantitative PCR data were analyzed by Student's $t$-test. The software package was Systat 11.0 (SPSS, Chicago, IL).

\section{RESULTS}

\section{Effect of BD-1063 on Ethanol Self-Administration in Nondependent and Withdrawn, Dependent Wistar Rats}

As shown in Figure 1 (top panel), treatment with the SigR antagonist $\mathrm{BD}-1063$ reduced ethanol responding (treatment: $\mathrm{F}(3,54)=5.41, P<0.01)$ in acutely withdrawn dependent Wistar rats, but not in nondependent rats (dependence $\times$ treatment: $\mathrm{F}(3,54)=2.92, P<0.05)$. In dependent rats, $\mathrm{BD}-1063$ reduced responding dose dependently as reflected in linear trend analysis (log-linear Dose effect: $\mathrm{F}(1,24)=16.52, P<0.01)$. Pairwise post hoc comparisons revealed that the doses of 7 and $11 \mathrm{mg} / \mathrm{kg}$ significantly reduced intake, and all 9 dependent rats self-administered less ethanol after treatment with $11 \mathrm{mg} / \mathrm{kg}$ BD-1063 than after vehicle treatment. In contrast, BD-1063 did not alter water responding in either group (treatment: $\mathrm{F}(3,54)=0.57$, n.s.; dependence $\times$ treatment: $F(3,54)=0.39$, n.s.; Figure 1 , bottom panel).

Among the nondependent rats, subgroup analysis showed that BD-1063 $(11 \mathrm{mg} / \mathrm{kg})$ tended to decrease self-administration in high responders $(38 \%$ reduction compared to vehicle, $P=0.08, n=4,0.80+0.06 \mathrm{~g} / \mathrm{kg})$, but not in low responders $(n=7,0.19+0.05 \mathrm{~g} / \mathrm{kg})$. Among the dependent rats, median split subgroup analysis showed that BD-1063 treatment significantly and comparably reduced self-administration in low responders (49\% reduction, $P=0.0001$; $n=5,0.84+0.14 \mathrm{~g} / \mathrm{kg})$ vs high responders $(34 \%$ reduction, $P=0.02 ; n=5,1.33+0.05 \mathrm{~g} / \mathrm{kg})$. Thus, BD-1063 reduced ethanol responding in both nondependent and dependent rodents that had high mean baseline ethanol self-administration $(\sim 0.8 \mathrm{~g} / \mathrm{kg}$ of ethanol). Above this threshold of intake, the relative suppression of ethanol self-administration by $\mathrm{BD}-1063$ was unrelated to baseline responding, arguing against a rate-dependent effect.

\section{Effect of BD-1063 on Saccharin Self-Administration in Wistar Rats}

As shown in Figure 2, treatment with BD-1063 did not reliably affect responding for saccharin in Wistar rats (treatment: $\mathrm{F}(3,21)=0.65$, n.s.). Moreover, no significant linear contrast effect of dose was observed. As desired, the saccharin solution maintained levels of responding under vehicle conditions that did not differ from those observed in withdrawn, ethanol-dependent rats. BD-1063 treatment also did not affect concurrent responding for water (treatment: $\mathrm{F}(3,21)=0.13$, n.s.), with no significant linear contrast effect of dose observed.

\section{Effect of BD-1063 on Ethanol Self-Administration in sP Rats}

As shown in Figure 3 (top panel), systemic treatment with the SigR antagonist $\mathrm{BD}-1063$ reduced ethanol responding of $\mathrm{sP}$ rats (treatment: $\mathrm{F}(4,32)=11.63, P<0.001$ ), in a dosedependent manner (log-linear Dose effect: $F(1,32)=44.90$, $P<0.001)$. Post hoc comparisons revealed that the $4.4,7$, and $11 \mathrm{mg} / \mathrm{kg}$ doses significantly reduced responding relative to vehicle conditions; all nine $\mathrm{sP}$ rats showed reduced ethanol self-administration following the $11 \mathrm{mg} / \mathrm{kg}$ dose. In contrast, responding for water was not significantly affected by BD1063 (treatment: $F(4,32)=0.45$, n.s.; Figure 3, bottom panel). Figure 4 shows the time course of BD-1063 action, with the drug reducing ethanol intake within the first $5 \mathrm{~min}$ of the session and the cumulative reduction persisting for the duration of the session ( $60 \mathrm{~min})$. Median split analysis again showed that BD-1063 achieved a similar relative suppression of ethanol self-administration in low responders $(42 \%$ reduction, $P=0.04 ; n=4,0.92+0.05 \mathrm{~g} / \mathrm{kg}) v s$ high responders (41\% reduction, $P<0.01 ; n=5,1.30+0.11 \mathrm{~g} / \mathrm{kg}$ ).

\section{Effect of BD-1063 on Saccharin Self-Administration in sP Rats}

Treatment with BD-1063 did not reliably affect saccharin self-administration in $\mathrm{sP}$ rats (treatment: $\mathrm{F}(4,24)=1.90$, n.s.), as shown in Figure 5. Though a linear contrast effect of Dose was observed $(\mathrm{F}(1,24)=5.24, \quad P=0.03)$, pairwise 

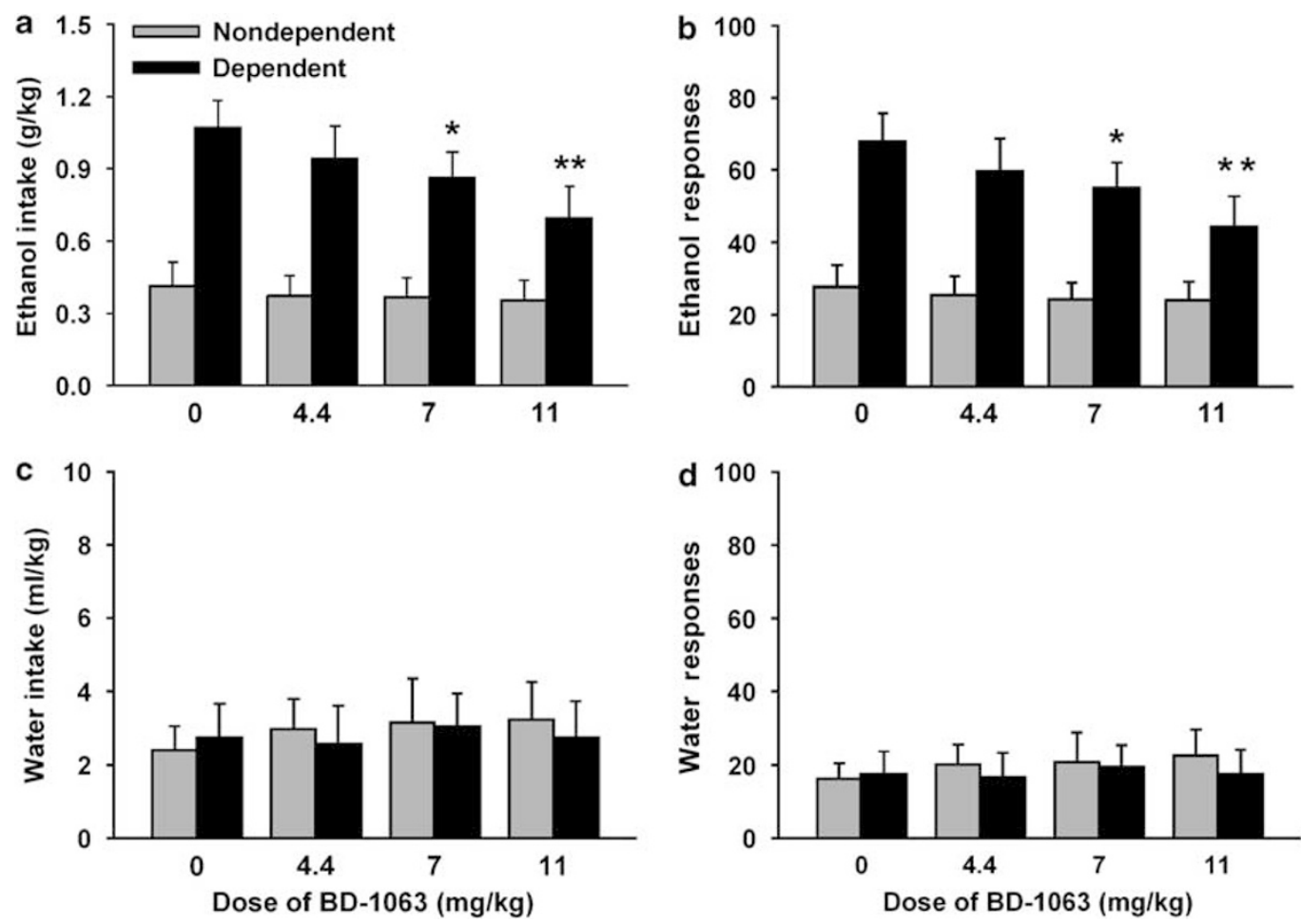

Figure I Effect of acute subcutaneous pretreatment (-15 min) with the $\sigma$-receptor (SigR) antagonist BD-I063 on ethanol (a and b) and water (c and d) self-administration on a fixed ratio-I schedule of reinforcement. Subjects were ethanol-dependent Wistar rats $(n=9)$, tested 6 -h into withdrawal from ethanol vapor, and nondependent Wistar rats $(n=1 \mathrm{I})$. Data represent mean + SEM intake, normalized for body weight (a and $c)$, or number of lever press responses ( $b$ and $d) .{ }^{*} p<0.05,{ }^{*} p<0.0$ I vs vehicle-treated group (Dunnett's test).


Figure 2 Effect of acute subcutaneous pretreatment $(-15 \mathrm{~min})$ with the $\sigma$-receptor (SigR) antagonist BD- 063 on saccharin (a) and water (b) selfadministration on a fixed ratio-I schedule of reinforcement in Wistar rats $(n=8)$. Data represent mean + SEM number of lever press responses. comparisons showed that no dose reduced responding relative to vehicle conditions. Moreover, the relative reduction in ethanol responding in $\mathrm{sP}$ rats elicited by $\mathrm{BD}$ $1063(11 \mathrm{mg} / \mathrm{kg})$ was greater in $\mathrm{sP}$ rats responding for ethanol than in those responding for saccharin (42 vs $15 \%$, respectively). As desired, the saccharin solution elicited levels of responding under vehicle conditions that were similar to sP rats responding for ethanol. BD-1063 treatment did not significantly affect water intake $(\mathrm{F}(4,24)=1.42$, n.s. $)$, and no significant linear contrast effect of dose was observed.

\section{Effect of BD-1063 on Progressive Ratio Responding for Ethanol in SP Rats}

As shown in Figure 6, systemic treatment with the SigR antagonist $\mathrm{BD}-1063$ reduced the break point of $\mathrm{sP}$ rats responding for ethanol under a PR schedule of reinforcement (treatment: $\mathrm{F}(4,40)=8.28, P<0.001$ ), in a dosedependent manner (log-linear dose effect: $\mathrm{F}(1,40)=22.77$, $P<0.001)$. BD-1063 treatment also dose dependently reduced the total number of responses emitted for ethanol (treatment: $\mathrm{F}(4,40)=8.56, P<0.001$; log-linear Dose effect: $\mathrm{F}(1,40)=23.46, P<0.001)$ as well as the total number of ethanol reinforcers earned (treatment: $\mathrm{F}(4,40)=7.88$, $P<0.001$; data not shown). Post hoc comparisons revealed that the $4.4,7$, and $11 \mathrm{mg} / \mathrm{kg}$ doses of BD-1063 significantly reduced each of the above measures. Responding at the inactive lever was not altered by BD-1063 treatment $(\mathrm{F}(4,40)=2.57$, n.s. $)$. 

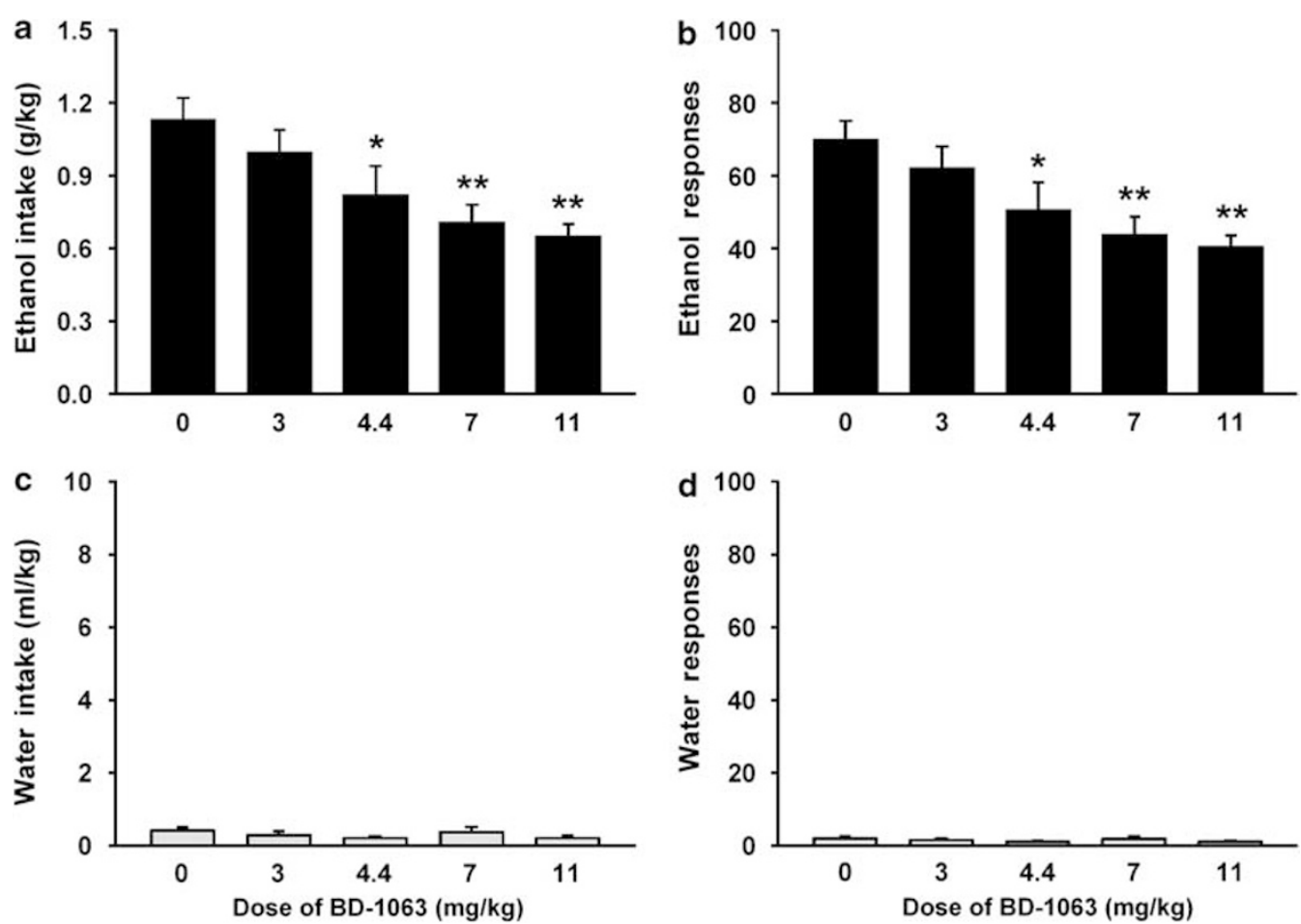

Figure 3 Effect of acute subcutaneous pretreatment (-15 min) with the $\sigma$-receptor (SigR) antagonist BD- I 063 on alcohol (a and b) and water (c and d) self-administration on a fixed ratio-I schedule of reinforcement in SP rats $(n=9)$. Data represent mean + SEM intake normalized for body weight (a and $c)$, or number of lever press responses ( $b$ and $d$ ). ${ }^{*} p<0.05,{ }^{*} * p<0.0$ I vs vehicle-treated group (Dunnett's test).

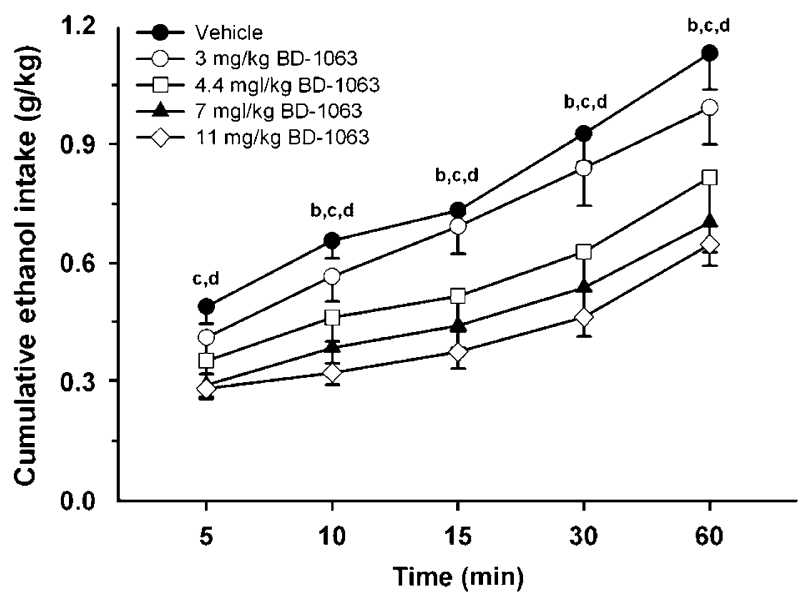

Figure 4 Time-course of the reduction of cumulative ethanol intake resulting from subcutaneous pretreatment with $\mathrm{BD}-1063$ in $\mathrm{sP}$ rats $(n=9)$. Graph shows the cumulative ethanol intake at 5, 10, 15, 30, and 60 min into the session of subjects shown in Figure 3. Data represent mean-SEM. $\mathrm{b}=$ dose of $4.4 \mathrm{mg} / \mathrm{kg}, \mathrm{c}=$ dose of $7 \mathrm{mg} / \mathrm{kg}, \mathrm{d}=$ dose of $1 \mathrm{Img} / \mathrm{kg}$, significantly different from vehicle (Dunnett's test).

\section{Sig-1R Gene Expression in sP Rats and in Acutely Withdrawn Dependent Wistar Rats}

Quantitative real-time PCR showed, as depicted in Figure 7, that Sig-1R mRNA levels were significantly lower in the nucleus accumbens of ethanol-naive sP rats $(t(14)=2.60$, $p<0.05)$ and $24-h$ withdrawn, ethanol-dependent rats $(t(16)=1.76, \quad p<0.05) \quad$ compared with ethanol-naive outbred Wistar controls. No significant differences were observed in the nucleus accumbens of 6-h withdrawn, ethanol-dependent rats $(t(14)=0.55$, n.s.). No differences were observed among groups in expression of Sig-1R mRNA within the ventral tegmental area, central nucleus of the amygdala or basolateral amygdala (data not shown).

\section{DISCUSSION}

This study shows that the preferential Sig-1R antagonist BD-1063 dose dependently and selectively reduced oral ethanol self-administration in two animal models of excessive ethanol drinking - acutely withdrawn, ethanol dependent outbred Wistar rats and genetically selected, alcohol-preferring $\mathrm{sP}$ rats. BD-1063 also reduced the motivation of sP rats to work to obtain alcohol. In contrast, BD-1063 did not reduce ethanol self-administration in nondependent control Wistar rats or comparably reduce self-administration of water or of an equally reinforcing saccharin solution. Both ethanol-naive sP rats and acutely withdrawn $(24 \mathrm{~h})$, ethanol-dependent Wistar rats showed decreased Sig-1R mRNA expression in the nucleus accumbens compared with ethanol-naive control Wistar rats. The results collectively support an endogenous role for brain Sig-1Rs in the modulation of excessive ethanol intake and reinforcement.

The highest dose of BD-1063 administered $(11 \mathrm{mg} / \mathrm{kg}$ of free base) decreased fixed-ratio operant responding for ethanol, a measure of ethanol's reinforcing properties with predictive validity for medications used to treat alcoholism (Altshuler et al, 1980; Czachowski et al, 2001; Johnson and 

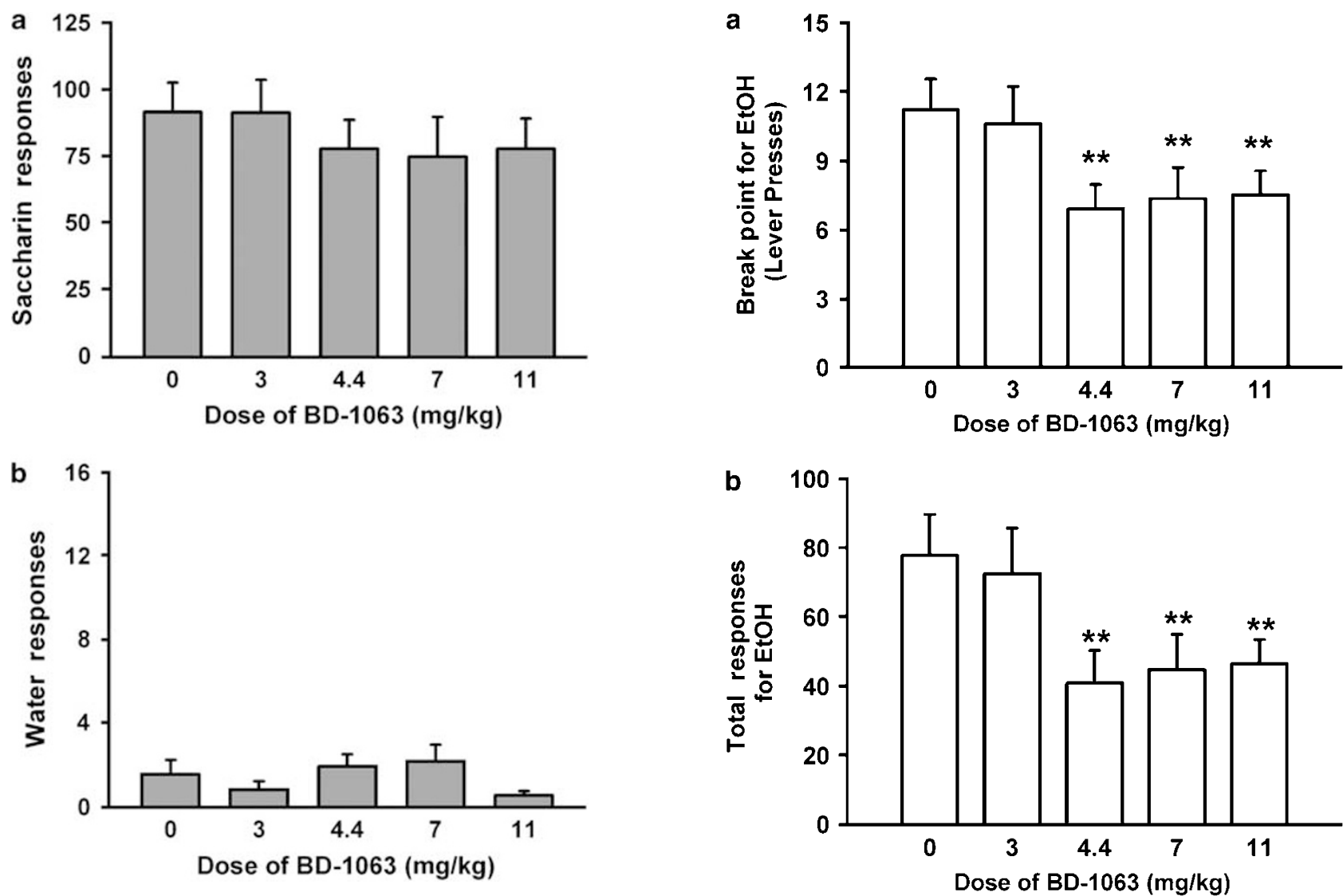

Figure 5 Effect of acute subcutaneous pretreatment $(-15 \mathrm{~min})$ with the $\sigma$-receptor (SigR) antagonist BD- 1063 on saccharin (a) and water (b) selfadministration on a fixed ratio-I schedule of reinforcement in $\mathrm{SP}$ rats $(n=8)$. Data represent the mean + SEM number of lever press responses.

Figure 6 Effect of acute subcutaneous pretreatment $(-15 \mathrm{~min})$ with the $\sigma$-receptor (SigR) antagonist BD-I063 on break point (a) and total responses (b) for ethanol in $\mathrm{SP}$ rats $(n=\mathrm{II})$ tested under a progressive ratio schedule of reinforcement. Data represent mean + SEM. $* * * 0.0$ I vs vehicle-treated group (Dunnett's test)

Ait-Daoud, 2000), by 37 and $42 \%$ in dependent Wistar and sP rats, respectively. Several control measures demonstrated the specificity of Sig-1R antagonist action on excessive ethanol self-administration, including no effect on mean ethanol self-administration of nondependent rats, on concurrent water self-administration, or on self-administration of an equally reinforcing saccharin solution. Also, arguing against a rate-dependent interpretation of BD-1063 action, median split analysis showed that BD-1063 similarly reduced ethanol self-administration of high $v s$ low responding ethanol-dependent and sP rats. Thus, BD-1063 did not reduce general behavior or produce rate-suppressant effects, consistent with previous reports showing lack of locomotor suppressant effect of $\mathrm{BD}-1063$, similar to the chemically related BD-1047, at doses up to $30 \mathrm{mg} / \mathrm{kg}$ (Brammer et al, 2006; Maurice et al, 2003; McCracken et al, 1999; Nguyen et al, 2005).

To address further the alternative explanation that the selective action of BD-1063 in models of excessive drinking was a rate-suppressive effect on the higher baseline responding of ethanol-dependent and $\mathrm{sP}$ rats, the effects of BD-1063 also were evaluated under a PR schedule of reinforcement. Under PR reinforcement schedules, ratio requirements increase with subsequent reinforcer deliveries, and the influence of local response rates on performance are reduced. BD-1063 potently $(4.4 \mathrm{mg} / \mathrm{kg})$ reduced the break point, an objective measure of the effort

an animal will expend to obtain a reinforcer that is sensitive both to the subjects' incentive state and to the reinforcers' stimulus properties (Walker et al, 2008). The ability of BD1063 to reduce break point also counters the alternative explanation that the drug acted by altering ethanol absorption or metabolism because the total amount of ethanol self-administered by rats under this schedule $(0.18 \mathrm{~g} / \mathrm{kg}$ under vehicle treatment $)$ would not result in significant BALs (personal observation). Thus, the SigR antagonist reduced not only ethanol intake, but also the work that rats would emit to obtain ethanol.

These results are broadly consistent with previous findings that the Sig-1R antagonist BD-1047 attenuated several behavioral and motivational effects of acute passive ethanol administration in mice (Maurice et al, 2003) including ethanol-induced locomotor activation and ethanol-induced place preference and taste aversion conditioning. Here, a different Sig-1R antagonist selectively reduced responding for ethanol in two distinct models of excessive ethanol self-administration, supporting the hypothesis that endogenous SigR signaling contributes to oral ethanol's reinforcing effects. However, BD-1063 did not reduce ethanol self-administration to control-like levels. Perhaps higher doses of BD-1063 could have eliminated the excess component of ethanol self-administration altogether. Alternatively, other transmitter systems likely independently 
Nucleus accumbens



Figure $7 \mathrm{Sig}-\mathrm{IR}$ mRNA expression in the nucleus accumbens of ethanol-naive Sardinian alcohol-preferring (SP) rats, ethanol-naive outbred Wistar control rats, and acutely withdrawn (6-h) Wistar rats previously made ethanol-dependent through intermittent exposure to ethanol vapors for 6 weeks (left panel, $n=7,9$, and 7, respectively) and ethanol-naive outbred Wistar control rats, and acutely withdrawn (24-h) Wistar rats (right panel $n=9$ and 7 , respectively). Data represent mean + SEM expressed as percent of the control group. ${ }^{*} p<0.05$ vs outbred control rats (Student's t-test).

contribute to the excess ethanol intake in these models (Funk et al, 2006; Walker et al, 2008; Roberto et al, 2008).

Previous studies have demonstrated that SigR blockade can attenuate several neurobehavioral effects of cocaine and methamphetamine, including the drugs' subjective (Katz et al, 2003), psychomotor stimulant (Liu and Matsumoto, 2008; Menkel et al, 1991; Ujike et al, 1992), rewarding (Romieu et al, 2000), and toxic (Matsumoto et al, 2001b; Maurice et al, 2002) effects. A recent study, however, observed that the SigR antagonist BD-1047 did not reduce nondependent intravenous cocaine self-administration (Martin-Fardon et al, 2007), unlike this study in which we observed suppression of oral ethanol self-administration by BD-1063. Several procedural differences may explain the discrepant findings, including major ones such as the substance of abuse under study, the antagonists and route of drug intake used, and the session duration. The subjects under study also may be critical because ethanol selfadministration was only reduced here in models of excessive self-administration and not in nondependent controls, a group more analogous to those of the previous cocaine self-administration study. Interestingly, BD-1047 did reduce reinstatement of cocaine-directed responding elicited by a drug-taking contextual stimulus (MartinFardon et al, 2007); it remains to be seen whether Sig-1R antagonists similarly suppress reinstatement of ethanoldirected responding.

The greater efficacy of the SigR antagonist in the two models of excessive drinking raises the possibility that withdrawn, ethanol-dependent rats and $\mathrm{sP}$ rats might both carry alterations in the expression or function of SigR sites or endogenous ligands, leading to an increased reinforcing efficacy of ethanol. In this study, quantitative real-time PCR showed that Sig-1R mRNA levels were modestly (15\%) but significantly lower in the nucleus accumbens of both sP rats and 24-h withdrawn, dependent Wistar rats. Similar to previous studies (Economidou et al, 2008; Hansson et al, 2007), outbred Wistar rats were used as the control group for both sP rats and outbred Wistar dependent rats in this study to allow a more direct comparison between these two animal models of excessive drinking. Using alcohol nonpreferring rats as a control group for $\mathrm{sP}$ rats also might have left it more ambiguous as to whether observed differences were associated with excessive drinking as opposed to ethanol aversion, which can be associated with molecular changes distinct from those which drive excess intake (Saba et al, 2001).

Reduced Sig-1R mRNA expression was not observed $6 \mathrm{~h}$ after cessation of ethanol vapor suggesting that the decrease may be a delayed transcriptional consequence of ethanol withdrawal, rather than of the ethanol exposure history per $s e$. A related question is why differences in Sig-1R mRNA levels were not observed between Wistar ethanol-naive and ethanol-dependent rats during early withdrawal (6h), a time point at which differences in ethanol self-administration and sensitivity to BD-1063 already were present. Perhaps Sig-1R activity is already altered at the 6-h time point at the ligand or receptor protein level due to the early stages or previous cycles of withdrawal, but a change in Sig-1R transcription takes longer to manifest. Such a delay might result if the decreased receptor mRNA expression occurs in response to heightened SigR ligand activity or per the slower time course of transcription $v s$ ligand release/ binding. Testing this hypothesis in future studies could involve measuring Sig-1R protein or endogenous ligands (once identified) during intoxication and 6-h withdrawal. In addition, differences in the experimental paradigms used for the behavioral $v s$ molecular studies may be relevant. Perhaps rats with a history of self-administering ethanol during withdrawal might show changes in Sig-1R mRNA levels at the earlier 6-h time point. To identify innate differences in sP rats, we measured Sig-1R mRNA levels in ethanol-naive rats in this study, rather than in rats that were acutely or historically self-administering ethanol. Ethanol drinking can differentially affect ethanol-naive alcoholpreferring rats, eliminating or introducing neurochemical and behavioral differences (Hansson et al, 2007; Katner and Weiss, 2001; Weiss et al, 1993), and it would be valuable in future studies also to examine differential changes in SigR systems that result from ethanol drinking in the groups studied here. As a first-priority study relevant to the current hypothesis, however, the present experiments identified the presence of innate differences in the SigR system of sP rats in relation to their outbred stock and showed that withdrawal from repeated ethanol exposure yielded an environmental phenocopy of this molecular correlate of the genetic propensity to drink ethanol.

Similar changes were not observed in the central or basolateral amygdala or ventral tegmental area, suggesting regional specificity. The nucleus accumbens, intimately related to reward-related processes, integrates limbic information related to memory, drive, and motivation with the generation of goal-directed behaviors (Carelli and Wightman, 2004; Pecina et al, 2006; Pennartz et al, 1994). The nucleus accumbens also is implicated in excessive alcohol drinking and the pathophysiology of dependence (Koob, 2003; Tupala and Tiihonen, 2004). Further studies 
are needed to determine the functional significance of the molecular difference shared by $\mathrm{sP}$ and withdrawn dependent rats. The decreased Sig-1R mRNA expression might represent a compensatory response to a higher availability of neuroactive steroids, putative endogenous SigR ligands (for a review see Maurice, 2004). Such an interpretation is consistent with the observed higher sensitivity to pharmacological blockade of SigR by BD-1063. Studies that localize the decrease in Sig-1 mRNA to the shell vs core nucleus accumbens subregions, that potentially relate observed mRNA differences to protein expression changes, that explore corresponding changes in putative endogenous SigR ligands, and that investigate the effects of brain sitespecific administration of Sig-1R ligands on the reinforcing effects of ethanol will be required.

Ethanol has not been shown to interact directly with SigRs, but SigRs ligands may alter reinforcing actions of ethanol by indirectly modulating activity of other ethanolsensitive transmitter systems; for example, SigR ligands affect synthesis, release, and uptake of dopamine (Bastianetto et al, 1995; Booth and Baldessarini, 1991; Weatherspoon and Werling, 1999; Weiser et al, 1995). The SigR agonists (+)pentazocine, (+)-SKF 10,047, and DUP 734 increased extracellular dopamine concentration and dopamine metabolism in the striatum (Iyengar et al, 1990), facilitating release through a nontransporter-mediated mechanism. In addition $(+)$ pentazocine enhanced amphetamine-stimulated DA release in striatal slices (Izenwasser et al, 1998). Electrophysiological studies also have shown a modulatory role of SigRs on the firing activity of both the A9 and the A10 dopaminergic pathways, with an activation of SigRs generally resulting in an increase in firing (Engberg and Wikstrom, 1991; Minabe et al, 1999; Sanchez-Arroyos and Guitart, 1999; Steinfels et al, 1989; Zhang et al, 1992). In addition, the SigR agonist PRE-084 dose dependently increased the functional coupling of dopamine receptors with G-proteins in dopaminergic terminal brain areas (Peeters et al, 2004). Based on these observations, SigR antagonists might attenuate ethanol reinforcement by influencing dopaminergic transmission, directly or indirectly, within the mesolimbic pathway.

Alternatively, the drive to consume ethanol and other drugs of abuse may interfere with the activity of one of the endoplasmic reticulum (ER) proteins recently shown to be associated with SigRs (Aydar et al, 2002; Hayashi and Su, 2001; Yamamoto et al, 2002). SigRs, subcellularly localized within perikarya and dendrites, are compartmentalized to lipid-enriched globular membranes (Alonso et al, 2000; Phan et al, 2003), such as mitochondria-associated membranes of the smooth ER. In the ER, Sig-1Rs associate with proteins such as inositol 1,4,5 triphosphate receptor type 3 (IP3R3), $\mathrm{K}^{+}$channel subunits, or the ER chaperone BiP (GRP78) and serve as chaperone molecules in response to $\mathrm{Ca}^{2+}$ depletion (Hayashi and $\left.\mathrm{Su}, 2001,2007\right)$. Sig-1Rs translocate following cellular stimuli, redistributing to the entire ER or to cell components, events that alter intracellular communication (Hayashi et al, 2000; Hayashi and Su, 2003a,b, 2007; Monnet et al, 2003; Morin-Surun et al, 1999). Thus, SigRs are putative sensors and/or modulators of neuronal intracellular $\mathrm{Ca}^{2+}$ mobilization, and consequently of extracellular $\mathrm{Ca}^{2+}$ influx. Such action could explain the broad neuromodulation of SigR on several neurotransmitter systems by SigRs (Maurice et al, 2002). Based on these observations, a SigR antagonist may attenuate ethanol reinforcement by interfering with the putative activation of intracellular calcium mobilization associated with the drive to excessively consume ethanol.

BD-1063 has preferential, nanomolar affinity for Sig-1Rs, being 30-fold selective for Sig-1R vs Sig-2R sites (Brammer et al, 2006; Matsumoto et al, 2001a). Still, it is possible that at the systemic doses administered here, BD-1063 binds both SigR subtypes. Although most studies implicate the Sig-1R subtype in the actions of drugs of abuse, a few lines of pharmacological evidence suggest that some actions may also (or alternatively) involve Sig-2Rs (Mach et al, 1999; Matsumoto and Mack, 2001; Matsumoto et al, 2001b, 2007; Nuwayhid and Werling, 2006). As the Sig-2R gene has not been cloned or predicted from homology, this study could only investigate changes in Sig-1R mRNA, with the results pointing to a role for the Sig-1R subtype in excessive drinking. Further studies can better define the relative roles of each subtype in ethanol reinforcement. In summary, a selective SigR antagonist preferentially diminishes ethanol reinforcement in models of excessive drinking. Control procedures rule out a nonspecific or rate-dependent suppression in responding or a generalized action on all reinforcers. The selective effects of blocking SigRs on excessive drinking suggest a potential mechanism for neuroadaptation that leads to excessive drinking and a potential target for medication development for treatment of alcoholism.

\section{ACKNOWLEDGEMENTS}

Research was supported by grants from the National Institute on Alcohol Abuse and Alcoholism (AA016731-01, AA012602 and 2P60AA006420-25), by the Pearson Center for Alcoholism and Addiction Research, and by the NIH Intramural Research Programs of the National Institute on Drug Abuse, the National Institute on Alcohol Abuse and Alcoholism, and the National Institute on Diabetes and Digestive and Kidney Diseases. This is article number 19646 from The Scripps Research Institute. We thank the excellent technical assistance of Molly Brennan, Jeanette Helfers, and Robert Lintz, and the editorial assistance of Mike Arends.

\section{DISCLOSURE/CONFLICTS OF INTEREST}

The authors declared no conflicts of interest.

\section{REFERENCES}

Alonso G, Phan V, Guillemain I, Saunier M, Legrand A, Anoal M et al (2000). Immunocytochemical localization of the sigma(1) receptor in the adult rat central nervous system. Neuroscience 97: 155-170.

Altshuler HL, Phillips PE, Feinhandler DA (1980). Alteration of ethanol self-administration by naltrexone. Life Sci 26: 679-688.

Aydar E, Palmer CP, Klyachko VA, Jackson MB (2002). The sigma receptor as a ligand-regulated auxiliary potassium channel subunit. Neuron 34: 399-410.

Bastianetto S, Rouquier L, Perrault G, Sanger DJ (1995). DTGinduced circling behaviour in rats may involve the interaction 
between sigma sites and nigro-striatal dopaminergic pathways. Neuropharmacology 34: 281-287.

Booth RG, Baldessarini RJ (1991). (+)-6,7-benzomorphan sigma ligands stimulate dopamine synthesis in rat corpus striatum tissue. Brain Res 557: 349-352.

Bouchard P, Quirion R (1997). [3H]1,3-di(2-tolyl)guanidine and $[3 \mathrm{H}](+)$ pentazocine binding sites in the rat brain: autoradiographic visualization of the putative sigmal and sigma2 receptor subtypes. Neuroscience 76: 467-477.

Brammer MK, Gilmore DL, Matsumoto RR (2006). Interactions between 3,4-methylenedioxymethamphetamine and sigmal receptors. Eur J Pharmacol 553: 141-145.

Carelli RM, Wightman RM (2004). Functional microcircuitry in the accumbens underlying drug addiction: insights from realtime signaling during behavior. Curr Opin Neurobiol 14: 763-768.

Colombo G (1997). ESBRA-Nordmann 1996 Award Lecture: ethanol drinking behaviour in Sardinian alcohol-preferring rats. Alcohol Alcohol 32: 443-453.

Colombo G, Agabio R, Lobina C, Reali R, Zocchi A, Fadda F et al (1995). Sardinian alcohol-preferring rats: a genetic animal model of anxiety. Physiol Behav 57: 1181-1185.

Czachowski CL, Legg BH, Samson HH (2001). Effects of acamprosate on ethanol-seeking and self-administration in the rat. Alcohol Clin Exp Res 25: 344-350.

de Costa BR, He XS, Linders JT, Dominguez C, Gu ZQ, Williams W et al (1993). Synthesis and evaluation of conformationally restricted N-[2-(3,4-dichlorophenyl)ethyl]-N-methyl-2-(1-pyrrolidinyl)ethylamines at sigma receptors. 2. Piperazines, bicyclic amines, bridged bicyclic amines, and miscellaneous compounds. J Med Chem 36: 2311-2320.

Economidou D, Hansson AC, Weiss F, Terasmaa A, Sommer WH, Cippitelli A et al (2008). Dysregulation of nociceptin/orphanin FQ activity in the amygdala is linked to excessive alcohol drinking in the rat. Biol Psychiatry 64: 211-218.

Engberg G, Wikstrom H (1991). Sigma-receptors: implication for the control of neuronal activity of nigral dopamine-containing neurons. Eur J Pharmacol 201: 199-202.

Funk CK, O’Dell LE, Crawford EF, Koob GF (2006). Corticotropinreleasing factor within the central nucleus of the amygdala mediates enhanced ethanol self-administration in withdrawn, ethanol-dependent rats. J Neurosci 26: 11324-11332.

Ganapathy ME, Prasad PD, Huang W, Seth P, Leibach FH, Ganapathy V (1999). Molecular and ligand-binding characterization of the sigma-receptor in the Jurkat human T lymphocyte cell line. J Pharmacol Exp Ther 289: 251-260.

Gundlach AL, Largent BL, Snyder SH (1985). Phencyclidine and sigma opiate receptors in brain: biochemical and autoradiographical differentiation. Eur J Pharmacol 113: 465-466.

Hanner M, Moebius FF, Flandorfer A, Knaus HG, Striessnig J, Kempner E et al (1996). Purification, molecular cloning, and expression of the mammalian sigmal-binding site. Proc Natl Acad Sci USA 93: 8072-8077.

Hansson AC, Cippitelli A, Sommer WH, Ciccocioppo R, Heilig M (2007). Region-specific down-regulation of Crhr1 gene expression in alcohol-preferring $\mathrm{msP}$ rats following ad lib access to alcohol. Addict Biol 12: 30-34.

Hayashi T, Maurice T, Su TP (2000). Ca(2+) signaling via sigma(1)-receptors: novel regulatory mechanism affecting intracellular $\mathrm{Ca}(2+)$ concentration. J Pharmacol Exp Ther 293: 788-798.

Hayashi T, Su TP (2001). Regulating ankyrin dynamics: roles of sigma-1 receptors. Proc Natl Acad Sci USA 98: 491-496.

Hayashi T, Su TP (2003a). Intracellular dynamics of sigma-1 receptors (sigma(1) binding sites) in NG108-15 cells. J Pharmacol Exp Ther 306: 726-733.

Hayashi T, Su TP (2003b). Sigma-1 receptors (sigma(1) binding sites) form raft-like microdomains and target lipid droplets on the endoplasmic reticulum: roles in endoplasmic reticulum lipid compartmentalization and export. J Pharmacol Exp Ther 306: 718-725.

Hayashi T, Su TP (2007). Sigma-1 receptor chaperones at the ERmitochondrion interface regulate $\mathrm{Ca}(2+)$ signaling and cell survival. Cell 131: 596-610.

Hellewell SB, Bowen WD (1990). A sigma-like binding site in rat pheochromocytoma (PC12) cells: decreased affinity for (+)benzomorphans and lower molecular weight suggest a different sigma receptor form from that of guinea pig brain. Brain Res 527: $244-253$.

Itzhak Y (1993). Repeated methamphetamine-treatment alters brain sigma receptors. Eur J Pharmacol 230: 243-244.

Iyengar S, Dilworth VM, Mick SJ, Contreras PC, Monahan JB, Rao TS et al (1990). Sigma receptors modulate both A9 and A10 dopaminergic neurons in the rat brain: functional interaction with NMDA receptors. Brain Res 524: 322-326.

Izenwasser S, Thompson-Montgomery D, Deben SE, Chowdhury IN, Werling LL (1998). Modulation of amphetamine-stimulated (transporter mediated) dopamine release in vitro by sigma2 receptor agonists and antagonists. Eur J Pharmacol 346: 189-196.

Johnson BA, Ait-Daoud N (2000). Neuropharmacological treatments for alcoholism: scientific basis and clinical findings. Psychopharmacology (Berl) 149: 327-344.

Katner SN, Weiss F (2001). Neurochemical characteristics associated with ethanol preference in selected alcohol-preferring and -nonpreferring rats: a quantitative microdialysis study. Alcohol Clin Exp Res 25: 198-205.

Katz JL, Libby TA, Kopajtic T, Husbands SM, Newman AH (2003). Behavioral effects of rimcazole analogues alone and in combination with cocaine. Eur J Pharmacol 468: 109-119.

Koob GF (2003). Alcoholism: allostasis and beyond. Alcohol Clin Exp Res 27: 232-243.

Koob GF, Sanna PP, Bloom FE (1998). Neuroscience of addiction. Neuron 21: 467-476.

Liu Y, Matsumoto RR (2008). Alterations in fra-2 and \{sigma\}-1 receptor gene and protein expression are associated with the development of cocaine-induced behavioral sensitization: time course and regional distribution studies. J Pharmacol Exp Ther 327: 187-195.

Lovinger DM, Crabbe JC (2005). Laboratory models of alcoholism: treatment target identification and insight into mechanisms. Nat Neurosci 8: 1471-1480.

Mach RH, Wu L, West T, Whirrett BR, Childers SR (1999). The analgesic tropane analogue (+/-)-SM 21 has a high affinity for sigma2 receptors. Life Sci 64: L131-L137.

Martin-Fardon R, Maurice T, Aujla H, Bowen WD, Weiss F (2007). Differential effects of sigmal receptor blockade on self-administration and conditioned reinstatement motivated by cocaine vs natural reward. Neuropsychopharmacology 32: 1967-1973.

Martin WR, Eades CG, Thompson JA, Huppler RE, Gilbert PE (1976). The effects of morphine- and nalorphine- like drugs in the nondependent and morphine-dependent chronic spinal dog. J Pharmacol Exp Ther 197: 517-532.

Matsumoto RR, Mack AL (2001a). (+/-)-SM 21 attenuates the convulsive and locomotor stimulatory effects of cocaine in mice. Eur J Pharmacol 417: R1-R2.

Matsumoto RR, McCracken KA, Friedman MJ, Pouw B, De Costa $B R$, Bowen WD (2001a). Conformationally restricted analogs of BD1008 and an antisense oligodeoxynucleotide targeting sigma1 receptors produce anti-cocaine effects in mice. Eur J Pharmacol 419: $163-174$.

Matsumoto RR, McCracken KA, Pouw B, Miller J, Bowen WD, Williams W et al (2001b). N-alkyl substituted analogs of the sigma receptor ligand $\mathrm{BD} 1008$ and traditional sigma receptor ligands affect cocaine-induced convulsions and lethality in mice. Eur J Pharmacol 411: 261-273. 
Matsumoto RR, Pouw B, Mack AL, Daniels A, Coop A (2007). Effects of UMB24 and (+/-)-SM 21, putative sigma2-preferring antagonists, on behavioral toxic and stimulant effects of cocaine in mice. Pharmacol Biochem Behav 86: 86-91.

Maurice T (2004). Neurosteroids and sigmal receptors, biochemical and behavioral relevance. Pharmacopsychiatry 37(Suppl 3): S171-S182.

Maurice T, Casalino M, Lacroix M, Romieu P (2003). Involvement of the sigma 1 receptor in the motivational effects of ethanol in mice. Pharmacol Biochem Behav 74: 869-876.

Maurice T, Martin-Fardon R, Romieu P, Matsumoto RR (2002). Sigma(1) (sigma(1)) receptor antagonists represent a new strategy against cocaine addiction and toxicity. Neurosci Biobehav Rev 26: 499-527.

Maurice T, Romieu P (2004). Involvement of the sigmal receptor in the appetitive effects of cocaine. Pharmacopsychiatry 37(Suppl 3): S198-S207.

McBride WJ, Li TK (1998). Animal models of alcoholism: neurobiology of high alcohol-drinking behavior in rodents. Crit Rev Neurobiol 12: 339-369.

McCracken KA, Bowen WD, De Costa BR, Matsumoto RR (1999). Two novel sigma receptor ligands, BD1047 and LR172, attenuate cocaine-induced toxicity and locomotor activity. Eur J Pharmacol 370: 225-232.

McLellan AT, Lewis DC, O’Brien CP, Kleber HD (2000). Drug dependence, a chronic medical illness: implications for treatment, insurance, and outcomes evaluation. JAMA 284: 1689-1695.

Mei J, Pasternak GW (2001). Molecular cloning and pharmacological characterization of the rat sigmal receptor. Biochem Pharmacol 62: 349-355.

Menkel M, Terry P, Pontecorvo M, Katz JL, Witkin JM (1991). Selective sigma ligands block stimulant effects of cocaine. Eur J Pharmacol 201: 251-252.

Minabe Y, Matsuno K, Ashby Jr CR (1999). Acute and chronic administration of the selective sigmal receptor agonist SA4503 significantly alters the activity of midbrain dopamine neurons in rats: an in vivo electrophysiological study. Synapse 33: 129-140.

Miyatake R, Furukawa A, Matsushita S, Higuchi S, Suwaki H (2004). Functional polymorphisms in the sigmal receptor gene associated with alcoholism. Biol Psychiatry 55: 85-90.

Moebius FF, Burrows GG, Hanner M, Schmid E, Striessnig J, Glossmann H (1993). Identification of a $27-\mathrm{kDa}$ high affinity phenylalkylamine-binding polypeptide as the sigma 1 binding site by photoaffinity labeling and ligand-directed antibodies. Mol Pharmacol 44: 966-971.

Monnet FP, Morin-Surun MP, Leger J, Combettes L (2003). Protein kinase C-dependent potentiation of intracellular calcium influx by sigmal receptor agonists in rat hippocampal neurons. J Pharmacol Exp Ther 307: 705-712.

Morin-Surun MP, Collin T, Denavit-Saubie M, Baulieu EE, Monnet FP (1999). Intracellular sigmal receptor modulates phospholipase $\mathrm{C}$ and protein kinase C activities in the brainstem. Proc Natl Acad Sci USA 96: 8196-8199.

Nguyen EC, McCracken KA, Liu Y, Pouw B, Matsumoto RR (2005). Involvement of sigma (sigma) receptors in the acute actions of methamphetamine: receptor binding and behavioral studies. Neuropharmacology 49: 638-645.

Nuwayhid SJ, Werling LL (2006). Sigma(2) (sigma(2)) receptors as a target for cocaine action in the rat striatum. Eur J Pharmacol 535: 98-103.

O'Dell LE, Roberts AJ, Smith RT, Koob GF (2004). Enhanced alcohol self-administration after intermittent versus continuous alcohol vapor exposure. Alcohol Clin Exp Res 28: 1676-1682.

Palkovits M, Brownstein MJ (1988). Maps and Guide to Microdissection of the Rat Brain. Elsevier: New York.
Pan YX, Mei J, Xu J, Wan BL, Zuckerman A, Pasternak GW (1998). Cloning and characterization of a mouse sigmal receptor. J Neurochem 70: 2279-2285.

Pecina S, Smith KS, Berridge KC (2006). Hedonic hot spots in the brain. Neuroscientist 12: 500-511.

Peeters M, Romieu P, Maurice T, Su TP, Maloteaux JM, Hermans E (2004). Involvement of the sigma 1 receptor in the modulation of dopaminergic transmission by amantadine. Eur J Neurosci 19: 2212-2220.

Pennartz CM, Groenewegen HJ, Lopes da Silva FH (1994). The nucleus accumbens as a complex of functionally distinct neuronal ensembles: an integration of behavioural, electrophysiological and anatomical data. Prog Neurobiol 42: 719-761.

Phan VL, Urani A, Sandillon F, Privat A, Maurice T (2003). Preserved sigmal (sigma1) receptor expression and behavioral efficacy in the aged C57BL/6 mouse. Neurobiol Aging 24: 865-881.

Quirion R, Hammer Jr RP, Herkenham M, Pert CB (1981). Phencyclidine (angel dust)/sigma 'opiate' receptor: visualization by tritium-sensitive film. Proc Natl Acad Sci USA 78: 5881-5885.

Rimondini R, Arlinde C, Sommer W, Heilig M (2002). Long-lasting increase in voluntary ethanol consumption and transcriptional regulation in the rat brain after intermittent exposure to alcohol. FASEB J 16: 27-35.

Roberto M, Gilpin NW, O'Dell LE, Cruz MT, Morse AC, Siggins GR et al (2008). Cellular and behavioral interactions of gabapentin with alcohol dependence. J Neurosci 28: 5762-5771.

Roberts AJ, Heyser CJ, Cole M, Griffin P, Koob GF (2000). Excessive ethanol drinking following a history of dependence: animal model of allostasis. Neuropsychopharmacology 22: 581-594.

Rogers J, Wiener SG, Bloom FE (1979). Long-term ethanol administration methods for rats: advantages of inhalation over intubation or liquid diets. Behav Neural Biol 27: 466-486.

Romieu P, Martin-Fardon R, Maurice T (2000). Involvement of the sigmal receptor in the cocaine-induced conditioned place preference. Neuroreport 11: 2885-2888.

Romieu P, Phan VL, Martin-Fardon R, Maurice T (2002). Involvement of the sigma(1) receptor in cocaine-induced conditioned place preference: possible dependence on dopamine uptake blockade. Neuropsychopharmacology 26: 444-455.

Saba L, Porcella A, Congeddu E, Colombo G, Peis M, Pistis M et al (2001). The R100Q mutation of the GABA(A) alpha(6) receptor subunit may contribute to voluntary aversion to ethanol in the sNP rat line. Brain Res Mol Brain Res 87: 263-270.

Sabino V, Cottone P, Koob GF, Steardo L, Lee MJ, Rice KC et al (2006). Dissociation between opioid and CRF1 antagonist sensitive drinking in Sardinian alcohol-preferring rats. Psychopharmacology (Berl) 189: 175-186.

Sanchez-Arroyos R, Guitart X (1999). Electrophysiological effects of E-5842, a sigmal receptor ligand and potential atypical antipsychotic, on A9 and A10 dopamine neurons. Eur J Pharmacol 378: 31-37.

Seth P, Fei YJ, Li HW, Huang W, Leibach FH, Ganapathy V (1998). Cloning and functional characterization of a sigma receptor from rat brain. $J$ Neurochem 70: 922-931.

Sharkey J, Glen KA, Wolfe S, Kuhar MJ (1988). Cocaine binding at sigma receptors. Eur J Pharmacol 149: 171-174.

Stefanski R, Justinova Z, Hayashi T, Takebayashi M, Goldberg SR, $\mathrm{Su}$ TP (2004). Sigmal receptor upregulation after chronic methamphetamine self-administration in rats: a study with yoked controls. Psychopharmacology (Berl) 175: 68-75.

Steinfels GF, Tam SW, Cook L (1989). Electrophysiological effects of selective sigma-receptor agonists, antagonists, and the selective phencyclidine receptor agonist MK-801 on midbrain dopamine neurons. Neuropsychopharmacology 2: 201-208.

Su TP, Hayashi T (2003). Understanding the molecular mechanism of sigma-1 receptors: towards a hypothesis that sigma-1 
receptors are intracellular amplifiers for signal transduction. Curr Med Chem 10: 2073-2080.

Takahashi S, Miwa T, Horikomi K (2000). Involvement of sigma 1 receptors in methamphetamine-induced behavioral sensitization in rats. Neurosci Lett 289: 21-24.

Takebayashi M, Hayashi T, Su TP (2002). Nerve growth factorinduced neurite sprouting in PC12 cells involves sigma-1 receptors: implications for antidepressants. J Pharmacol Exp Ther 303: 1227-1237.

Tupala E, Tiihonen J (2004). Dopamine and alcoholism: neurobiological basis of ethanol abuse. Prog Neuropsychopharmacol Biol Psychiatry 28: 1221-1247.

Ujike H, Okumura K, Zushi Y, Akiyama K, Otsuki S (1992). Persistent supersensitivity of sigma receptors develops during repeated methamphetamine treatment. Eur J Pharmacol 211: 323-328.

Vengeliene V, Bilbao A, Molander A, Spanagel R (2008). Neuropharmacology of alcohol addiction. Br J Pharmacol 154: 299-315.

Walker BM, Rasmussen DD, Raskind MA, Koob GF (2008). alpha1noradrenergic receptor antagonism blocks dependence-induced increases in responding for ethanol. Alcohol 42: 91-97.

Walker JM, Bowen WD, Walker FO, Matsumoto RR, De CB, Rice KC (1990). Sigma receptors: biology and function. Pharmacol Rev 42: 355-402.
Weatherspoon JK, Werling LL (1999). Modulation of amphetamine-stimulated $[3 \mathrm{H}]$ dopamine release from rat pheochromocytoma (PC12) cells by sigma type 2 receptors. J Pharmacol Exp Ther 289: 278-284.

Weiser SD, Patrick SL, Mascarella SW, Downing-Park J, Bai X, Carroll FI et al (1995). Stimulation of rat striatal tyrosine hydroxylase activity following intranigral administration of sigma receptor ligands. Eur J Pharmacol 275: 1-7.

Weiss F, Lorang MT, Bloom FE, Koob GF (1993). Oral alcohol selfadministration stimulates dopamine release in the rat nucleus accumbens: genetic and motivational determinants. J Pharmacol Exp Ther 267: 250-258.

Witkin JM, Terry P, Menkel M, Hickey P, Pontecorvo M, Ferkany J et al (1993). Effects of the selective sigma receptor ligand, 6-[6(4-hydroxypiperidinyl)hexyloxy]-3-methylflavone (NPC 16377), on behavioral and toxic effects of cocaine. J Pharmacol Exp Ther 266: 473-482.

Yamamoto H, Kametani F, Namiki Y, Yamamoto T, Karasawa J, Shen $\mathrm{H}$ et al (2002). Identification of GRP78 as a type-1 sigma receptor (SigmaR1)-associated protein. Society for Neuroscience Abstract Program \#833.839.

Zhang J, Chiodo LA, Wettstein JG, Junien JL, Freeman AS (1992). Acute effects of sigma ligands on the electrophysiological activity of rat nigrostriatal and mesoaccumbal dopaminergic neurons. Synapse 11: 267-278. 